\title{
The Impact of Tax Incentives on Foreign Direct Investment in Indonesia
}

\author{
Rotua Andriyati Siregar \\ University of Indonesia \\ The Australian National University \\ Arianto Patunru \\ The Australian National University
}

\begin{abstract}
Using the data from twenty-two partner countries in 1999 to 2018, this paper presents the impact of tax incentives on foreign direct investment (FDI) in Indonesia. A fixed-effect and least square dummy variable analysis are used to determine the direction and significance of tax incentives in its correlation with FDI together with other FDI determinant. The main finding shows that as tax incentives increase, the FDI flow decreases significantly. However, the corporate income tax (CIT) rate used as investment cost proxy shows that as it decreases the FDI flow will increase.
\end{abstract}

Keywords: Corporate income tax, FDI, Tax incentives, Gravity model

\section{Introduction}

It is widely accepted that foreign direct investment (FDI) is one of the economic performance determinants (Mengistu \& Adams, 2007). FDI is defined as investment made to build a long-term interest and control in an economy represented by at least ten per cent voting power in the management (Easson 1992; Moosa 2002). FDI has an immense contribution in bringing capital to the host country. The other advantages are it also provides access for local enterprises to the international market, improves labour development, enhances the transfer knowledge, and promotes technological productivity (OECD 2008). Subsequently, these drive many countries to compete in attracting investment by offering various incentives.

The neoclassical investment theory states that firms' primary purpose is to maximise profit; therefore, they tend to accumulate the capital if the benefit outweighs the cost (Popescu 2014; Bellak et al. 2008). If the cost of capital can be reduced by taking the tax reduction benefit, then they are motivated to take it as incentives to increase investment. It is in line with the study that explains that tax variables significantly affect FDI inward in seven developed countries and the US (Devereux \& Freeman 1995; Hines 1996). Another study by Klemm and Van Parys (2012) also finds that corporate income tax rate reduction significantly stimulates FDI in Latin American and African countries. Besides, they show that the tax holiday period has a positive relationship with FDI except in Africa.

On the contrary, Fowowe (2013), using private investment and FDI in Nigeria as dependent variables in his study, found that tax incentives significantly negatively correlate with those variables. Furthermore, the result suggests that infrastructure and macroeconomic stability play more prominent roles than fiscal incentives in promoting investment, especially in developing countries. Similar finding by Maksimovska-Veljanovski et al. (2015) was that though some Southeast European countries offer tax incentives, their FDI inflows decrease. In line with them, Hsu et al. (2019) also argue that one of the factors of tax incentives policy elimination in China in 2018 was its insignificant contribution to FDI. Moreover, they find that geographic location and market size have more contribution to FDI than tax incentives.

UNCTAD (2008) defines tax incentives as incentives that could reduce firms' 
tax liability such that they are attracted to invest in certain projects or geographic areas. Tax incentives can bring several advantages for host countries, such as boosting economic growth, increasing foreign capital, allowing technology and skills transfer, and promote product diversification. Type of incentives offered is based on these. For example, tax holidays, tax allowance, accelerated depreciation, and exemption from import duties on capital goods or input related to production. The requirements or regulations for each type of incentives are different among countries.

Indonesia is the largest economy in Southeast Asia which has impressive development for the past few decades. Since the Asian financial crisis in 1997-1998, Indonesian growth has been increasing significantly (World Bank 2020). It also managed to keep the growth from plummeting and then revived from the impact of the global financial crisis in 20082009 that can be identified in Figure 1.

Figure 1. Growth Rate of GDP Based on Constant Local Currency, 1999-2018

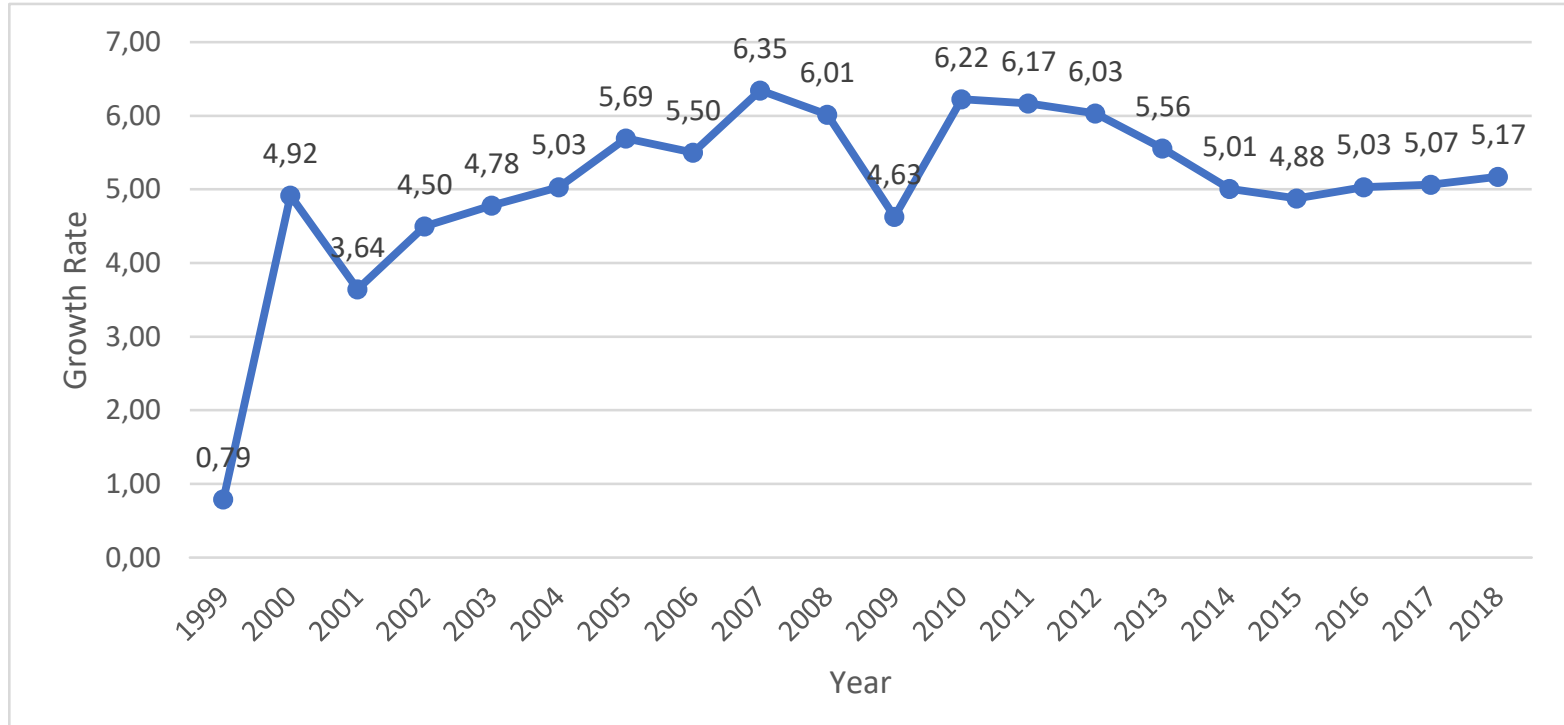

Source: World Bank Data (2020)

Since then, the government has put investment, especially foreign investment, as a priority in its economic policy. The total FDI realisation from
1999 to 2018 tends to increase despite a slight fall in 2018, as shown in Figure 2.

Figure 2. Total Foreign Direct Investment Realisation, 1999-2018

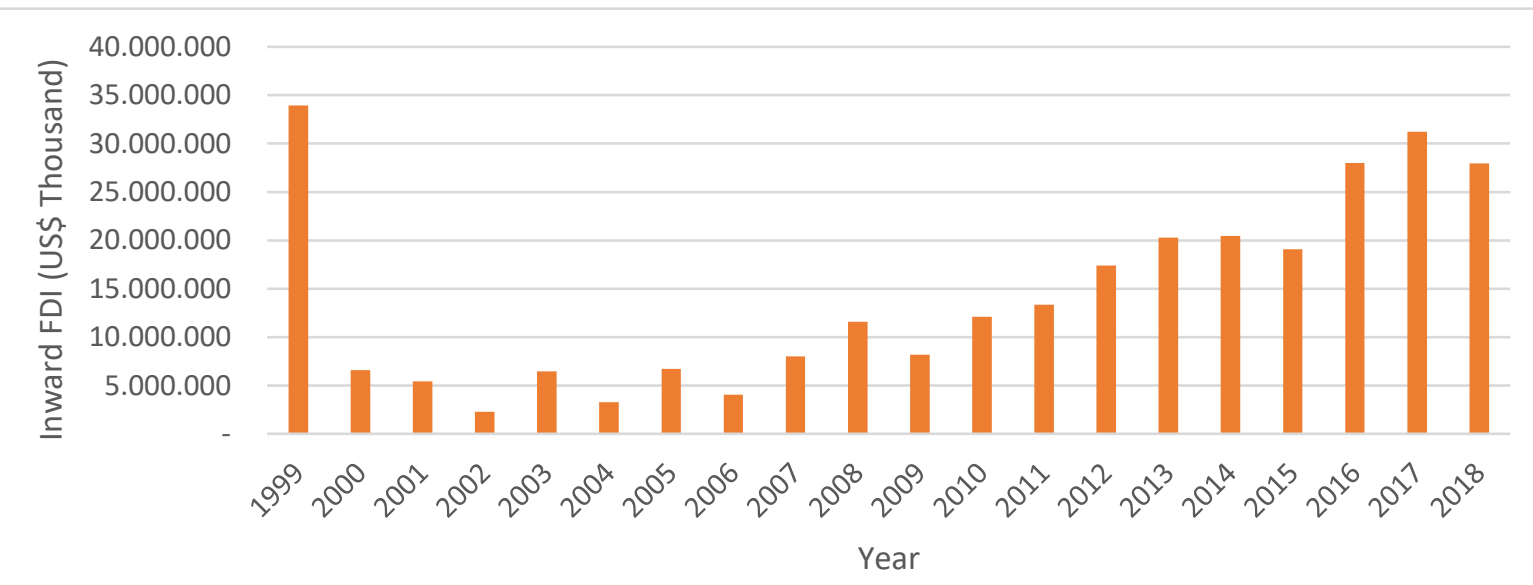

Source: Indonesia Investment Coordinating Board (2020) 
The data also shows that FDI inflow increase with economic growth which can be seen in Figure 3. Tax facilities are still believed effective in attracting FDI; therefore, the government regularly monitors and evaluates the implementation.

Figure 3. Ratio FDI to GDP and Growth in Indonesia, 1999-2018

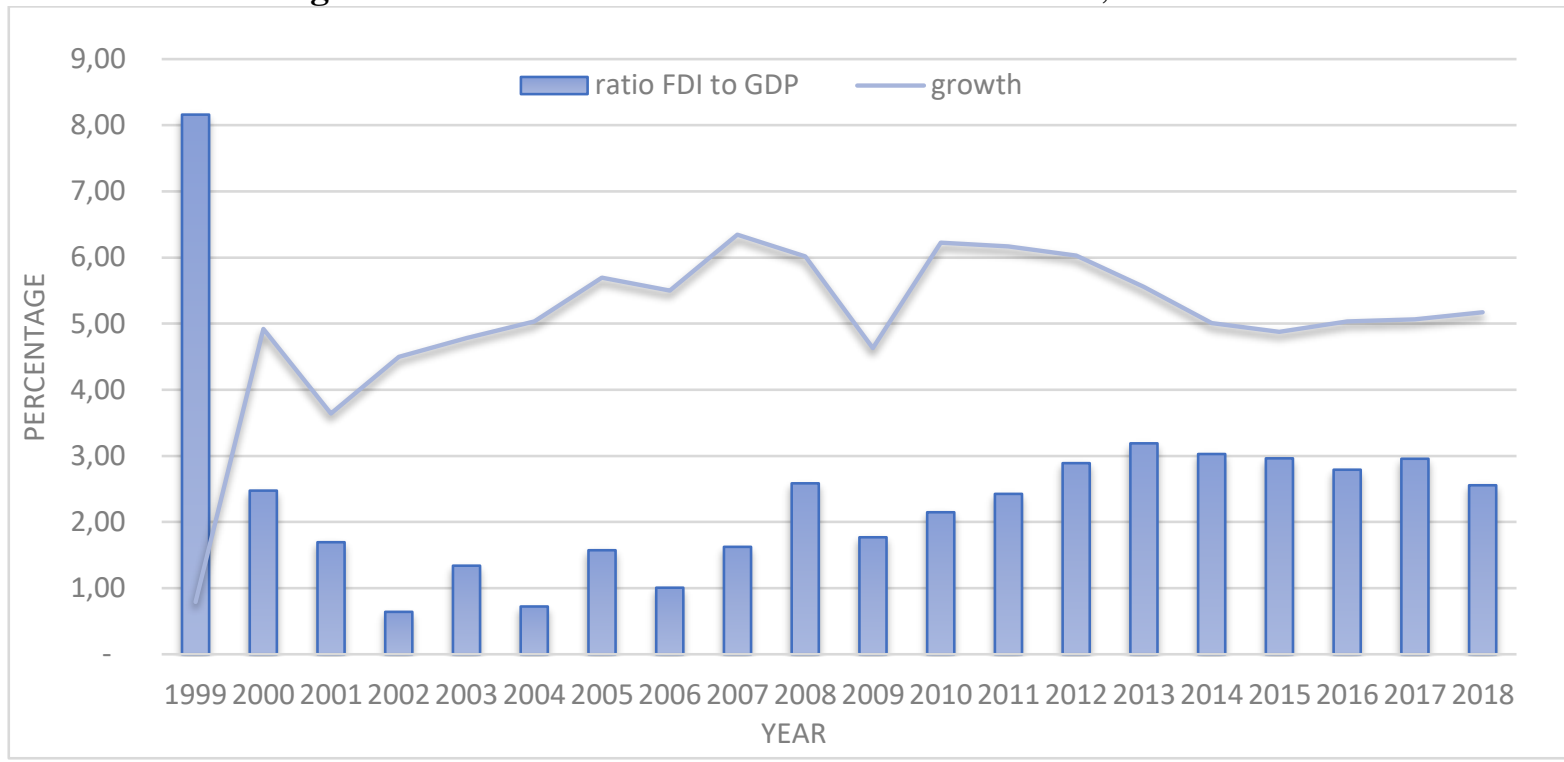

Source: Indonesia Investment Coordinating Board (2020), World Bank (2020)

There have been a series of law amendments regarding tax incentives in Indonesia. The types of tax incentives vary from targeted investment to a combination of targeted and general tax incentives. It was started in 1958 with Law No. 78 the Year 1958, then revised with Law No. 1 the Year 1967, Law No. 11 the Year 1970 until it was eliminated with Law No. 7 the Year 1983. In 2007, the government reformed its tax policy by passing tax incentives regulation, especially Tax Holiday and Tax Allowance with Law No. 25 the Year 2007. After that, the law has been regularly evaluated based on its effectiveness and efficiency, followed by policy and regulation changes.

Tax holiday and tax allowance are two types of tax incentives that Indonesia's government mainly uses to attract investors. The regulation regarding tax holiday has been regularly amended since 2015. First, Regulation of the Minister of Finance Number 159/PMK.010/2015 concerning the granting of corporate income tax reduction facility. Second, Regulation of the Minister of Finance Number 103/PMK.010/2016 concerning Amendment to Regulation of the Minister of Finance Number 159/PMK.010/2015 concerning the Granting of Corporate Income
Tax Reduction Facility. Next, Regulation of the Minister of Finance Number 35/PMK.010/2018 concerning the granting of corporate income tax reduction facility. Lastly, Regulation of the Minister of Finance Number 150/PMK.010/2018 concerning the granting of corporate income tax reduction facility.

Similar to tax holiday, tax allowance has also been amended since 2015. First, Government Regulation Number 18 the Year 2015 concerning income tax facility for capital investment in certain business sectors or regions. Second, Government Regulation Number 9 the Year 2016 concerning Amendment to Government Regulation Number 18 the Year 2015 concerning income tax facility for capital investment in certain business sectors or regions. Lastly, Government Regulation Number 78 the Year 2019 concerning income tax facility for capital investment in certain business sectors or regions.

As stated in both tax holiday and tax allowance regulations, the purpose of those granting facilities is to encourage direct investment in Indonesia, especially FDI. Therefore, the government regularly evaluates the incentives' implementation by analysing the number of companies that utilised the facilities, as shown in Figure 4. 
Figure 4. Number of Investors Granted for Tax Allowance and Tax Holiday, 1999-2018

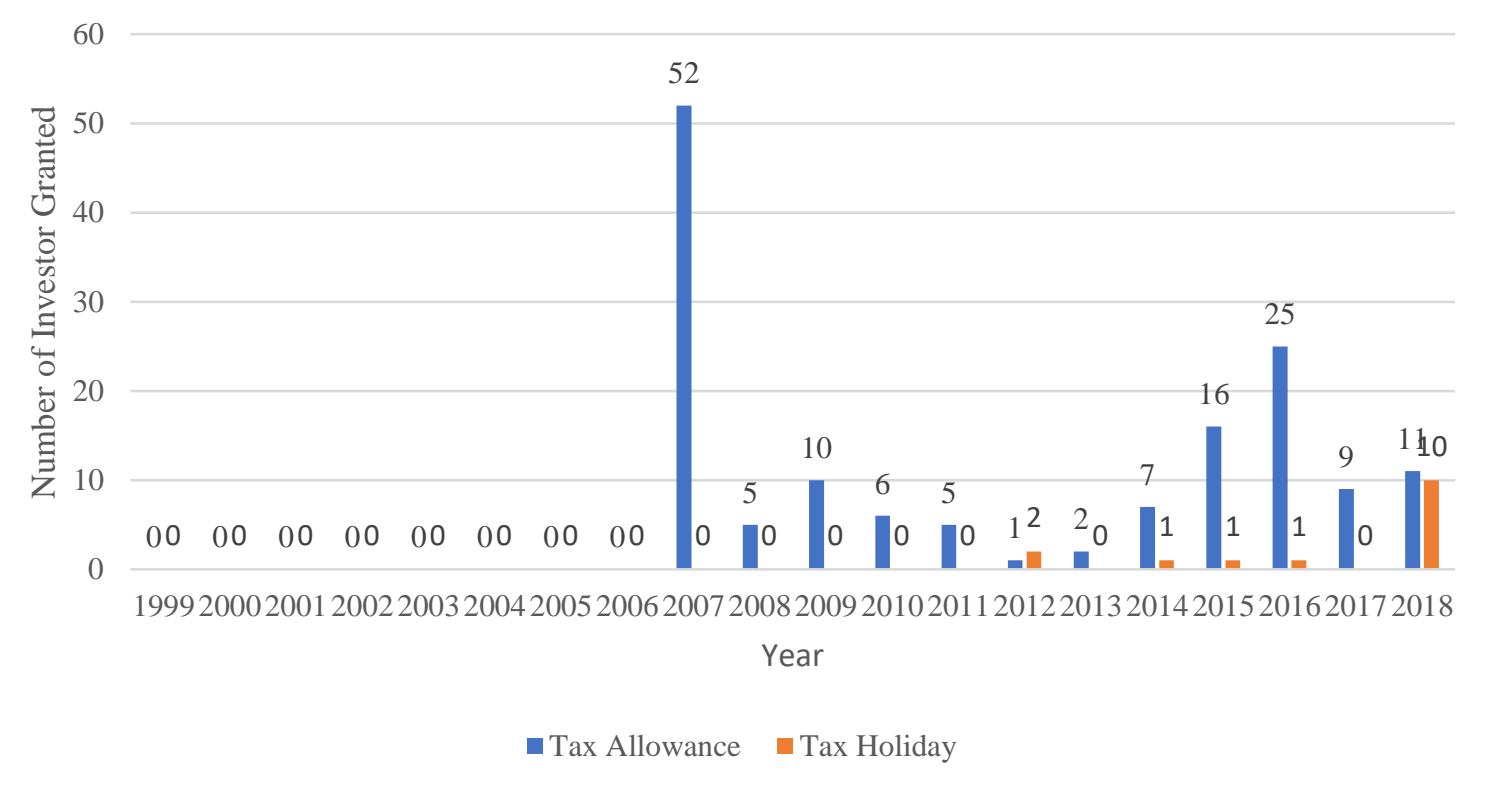

Source: Directorate General of Taxes (2020)

This trend shows that there has been a fluctuation in companies granted for tax allowance and tax holiday. Based on this data, the government has made a series of amendments which include changes in several points. First, the application procedures would be more straightforward and transparent by introducing the Online Single Submission system. Second, eligibility criteria for business sectors or regions include the change in negative investment list and standard of industrial classification. Third, incentives value benefits, including the change in cost recovery, accelerated depreciation, or tax losses. The reform has been expected to attract more investors and foreign ownership, hence promoting economic growth.

Based on this background, it is crucial to study the implementation of tax incentives after it was introduced again in 2007 and its correlation to FDI in Indonesia since the benefits for FDI remains unclear. Using data from 22 countries from 1999 to 2018, this study aims to measure the impact of tax incentives policy on enhancing FDI in Indonesia. It also helps to determine the other factors that could affect FDI significantly. Finally, this study will show some policy implications from the findings that might help decision-makers determine whether the implementation of tax incentives is necessary.
The paper is organised into five sections. Section one explains a brief theory and introduction of the issues. Section two describes an overview of theoretical and existing literature on tax incentives, FDI, and other factors that might affect FDI. The third section provides the data and methods used for the analysis. Section four discusses the results and findings. The last section concludes and proposes policy implications.

\section{Literature Review}

\section{Tax Incentives}

There are some definitions of tax incentives as a part of investment stimulus. James (2009) defines tax incentives as an exception from general tax rules that tax incentives are a special tax reduction to certain investment projects that fulfil several required criteria from a statutory perspective applied for certain types of investment in the form of tax liability reductions. Zee at al. (2002) defines tax incentives based on two terms; statutory and effective terms. Tax incentives are a special tax reduction to certain investment projects that fulfil several required criteria from a statutory perspective. It means that a general tax reduction is excluded from this definition. From an effective perspective, tax incentives generate a lower effective tax rate than the non-incentive tax rate. 
The relationship between tax incentives and FDI has been studied for decades. Previous studies find that different types of tax incentives may have a different result depending on various conditions. Paun (2019) using eleven EU countries from 2005 to 2015, finds that corporate tax reductions contribute to FDI inflow. However, other factors, such as unemployment and infrastructure, have a more significant impact on FDI. The national income level also matters in its effectiveness since the result could be different in developed countries than in developing countries. For example, the tax holiday is widely used in developing countries and Sub-Saharan Africa (Keen and Mansour 2009).

In Indonesia, a study by Wells and Allen (2001) found that after eliminating tax holidays and replacing it with general corporate tax rate reduction in 1984, the investment was unlikely impacted. Indonesia first introduced a tax holiday in 1967 with the primary purpose is to attract foreign investment until it expanded to domestic investment. However, since most large companies had invested in Indonesia, the government began to evaluate its tax policy. It started by reducing the corporate rate to 35 per cent from 60 per cent, which was considered high among home countries. Furthermore, it also passed the double tax treaties regulation that is beneficial for foreign investors regarding dividend withholding taxes. As a result, tax holidays became ineffective and inefficient.

They also argue that the termination of tax holidays in 1984 considered disadvantages both for home countries and Indonesia. It could lead to higher tax payments for home countries since some countries apply lower foreign tax credit policy. For Indonesia, this incentive could distort many sectors from various firms that tend to benefit large investors. It is in line with Zee at al. (2002) who explain that tax incentive potentially negatively impact if it is not designed and implemented well. First, they could undermine the tax base since many highprofitable investments are still attractive even without tax incentives. Secondly, there would be resource allocation distortion for tax advantages rather than its productivity. Lastly, in a weak institution, it could lead to corruption and rent-seeking activities.

After the elimination in 1984, the Indonesian government reintroduced tax holidays in 2007 and tax allowances in 2008. As of 2019, there are several types of fiscal incentives in Indonesia, which briefly described as follows:

1. Tax holidays

This incentive is granted to pioneer industries in the form of CIT rate reduction based on the industries' main activities. Besides, according to the regulation by Minister of Finance No. 150 the year 2018, the companies will be granted 100 per cent CIT rate reduction for a certain amount of investment and period.

2. Tax allowance

This incentive gives facilities in the form of net income reduction maximum 30 per cent of total investment, prorated at five per cent, which required the companies to have six years of production and asset holding in Indonesia. Other facilities include accelerated depreciation or accelerated amortisation, withholding tax up to ten per cent on dividend paid to a non-resident, and companies loss compensation.

3. Import Duties Exemption

Firms will be granted a zero per cent final tariff of their production or projects reach 30 per cent above their capacity target. It is also applied for import of electricity capital goods for a maximum of three years period.

4. Bonded Zones

This includes an exemption for valued added tax on luxury goods, import duty, and imported goods.

5. Free Trade Zones

All the transaction in these special areas is exempted from import duty, excise, and other taxes related to import.

\section{Foreign Direct Investment}

In the liberalisation era, openness to trade and foreign capital becomes a significant factor determining a country's economic performance (Thirlwall 2011). FDI has been known as an essential source of capital for developing countries. There are numerous definitions of FDI by scholars. Some of them define it as a process that involves acquiring asset ownership to control power over firm activities in another country (Moosa 2002; OECD 2008). Besides, as a source of funds, FDI also has other advantages. First, FDI flows are more stable than portfolio investment since they guarantee a long-term commitment. Secondly, it could 
bring technology advancement and human skills through training. It raises the rate of employment since a new investment might need new production facilities. Thirdly, it could increase the income and welfare of society in the host country. It induces competition and open access to the international market; therefore, productivity growth.

It is generally accepted that FDI flows are likely to be affected by economic factors. However, Tocar (2018) argues that such factors are not enough to explain the FDI destination. Further, he distinguishes the FDI determinants by economic and non-economic factors. It is in line with Dunning (2004; UN 1998) who summarise the FDI determinant for host countries, as shown in Table 2.

Among all the factors that might affect FDI, this paper will use both economic and noneconomic factors. It will use market size and cost that occurred from and within the host economy from economic factors. From noneconomic factors, it will use a policy framework for FDI, which are macroeconomic stability and taxation policy, and business facilitation which is represented by institutional and infrastructure quality. Further discussion will be shown as follows.

Table 2. FDI Determinants in Host Countries

\begin{tabular}{|c|c|c|}
\hline Host country determinants & Type of FDI & Principal economic determinants in host countries \\
\hline $\begin{array}{l}\text { 1. Policy framework for FDI } \\
\text { - Economic, political and social stability } \\
\text { - Rules regarding entry and operations } \\
\text { - Standards of treatment of foreign affiliates } \\
\text { - Policies on functioning and structure of } \\
\text { markets (especially competition and M \& } \\
\text { A policies) } \\
\text { - Bilateral international agreements on FDI } \\
\text { - Privatization and price reform policies } \\
\text { - Trade policy (tariffs and NTBs) and stable } \\
\text { exchange rates } \\
\text { - Taxation policy (including tax credits) } \\
\text { - Industrial/regional policies } \\
\text { 2. Economic determinants } \\
\text { 3. Business facilitation } \\
\text { - Encouragement of entrepreneurship } \\
\text { - Investment incentives and promotion } \\
\text { schemes } \\
\text { - Form and quality of legal property system } \\
\text { - Protection of intellectual property rights } \\
\text { - Social amenities (bilingual schools, } \\
\text { - Pousing, quality of life, etc.) } \\
\text { Pre- and post-investment services (e.g., one } \\
\text { stop shopping) } \\
\text { - Good institutional infrastructure and } \\
\text { support, e.g., banking, legal, accountancy, } \\
\text { services } \\
\text { - Social capital } \\
\text { - Region-based cluster and network } \\
\text { enhancement } \\
\text { - Legislation/policies designed to reduce } \\
\text { corruption, corporate malfeasance etc. }\end{array}$ & C Efficiency-seeking & $\begin{array}{l}\text { - Market size and per capita income } \\
\text { - Market growth } \\
\text { - Access to regional and global markets } \\
\text { - Country specific consumer preferences } \\
\text { - Structure of markets } \\
\text { - Psychic/Institutional distance } \\
\text { - Land and building costs: rents and rates } \\
\text { - Cost and quality of raw materials, components, } \\
\text { parts } \\
\text { - Low cost unskilled labour } \\
\text { - Availability, quality \& cost of skilled labor } \\
\text { - Cost of resources and capabilities listed under B } \\
\text { adjusted for productivity of labour inputs } \\
\text { - Other input costs, e.g., transport and } \\
\text { communication costs to, from and within, host } \\
\text { economy } \\
\text { - Membership of a regional integration agreement } \\
\text { conducive to promoting a more cost-effective } \\
\text { inter-country division of labour } \\
\text { - Quality of market enabling } \\
\text { institutions/enforcement mechanisms. } \\
\text { - Quality of technological, managerial, relational } \\
\text { and other created assets } \\
\text { - Physical infrastructure (ports, roads, power, } \\
\text { telecommunications) } \\
\text { - Contents of macro-innovatory, entrepreneurial \& } \\
\text { competitive enhancing educational institutions } \\
\text { - Mindsets, institutions and policies towards } \\
\text { economic growth/development }\end{array}$ \\
\hline
\end{tabular}

Source: UN (1998) and Dunning (2004)

From the economic point of view, the GDP's market size has been widely studied as it is an essential aspect of the FDI flows. The larger market of host countries would result in the larger FDI flow into the country since the investors cannot only participate in production but also sell their products domestically (Sharma \& Bandara 2010). Some studies use different terms for GDP as market size indicator, such as economic size (Tang 2011; Jurcau et al. 2011), market size (Mateev 2009; Riedl 2010), or straightforwardly, GDP per capita (Chakrabarti 2001). Most of the results show a positive correlation with FDI (Mottaleb et al. 2010; Wheeler and Mody 1992; Chakrabarti 2001).

The second economic aspect is the distance of two countries which represent the cost. The further the distance of the home and the house countries, the lower the FDI inflows. It is confirmed by the findings of previous studies, although they were using different variants. Mateev (2009) used the capitals' route 
distance between the two countries calculated in kilometres, while Siegel et al. (2013) used the minimum geographic distance. Besides, Crespo and Fontoura (2007) highlighted the regional effect's factor, mentioning the geographical dimension in FDI spillovers.

On the other hand, non-economic factor, namely the economic stability, is also examined by some studies. One of the macroeconomic factors of foreign investment is the exchange rate. Arbatli (2011) states that two variables could be used to analyse it, real exchange rate and exchange rate classification. According to the study, the real exchange rate does not significantly affect the FDI, while the latter has a more substantial impact by introducing the dummy variables of IMF's de facto classification of exchange rate arrangement. Moreover, the effects of macroeconomic instability, including inflation rates, exchange rate volatility, and high external debts are also considered as the substantial determinants of FDI in developing countries (e.g. Noorbakhsh et al. 2001; Mottaleb and Kalirajan 2010). The stable macroeconomic environment is preferable to foreign investors because it reflects certainty. The change in consumer price index (CPI) represents the inflation rate, which further reflects the macroeconomic instability. Asiedu (2002) examined the FDIs' flow to 22 countries in Sub Saharan Africa from 1984 to 2000 and concluded that inflation has a significant negative effect on the FDI inflows.

Another factor, CIT, is expected to affect the return of investments, hence the FDI decisions. According to Arbatli (2011) and Tang (2011), higher Corporate Tax Rates significantly discourage FDI flows. However, Hayakawa et al. (2013) suggest that the tax impact depends on the model's parameters. As a result, the economy's logic should be presented in an appropriate assumption with empirical evidence.

Moreover, the readiness of adequate infrastructure quality in the host country is also a vital part of the production chain because it is directly related to the supply and distribution processes of distribution factors. Countries with well-developed infrastructures would be more attractive places for foreign investors to place their investments than countries with less developed infrastructure since it will result in the higher cost of business operations and decrease the return on investment. It is coherent with the findings from several studies. For instance, Wheeler and Mody (1992) find that the quality of available infrastructure for developing countries is an essential aspect for FDI from the US. However, it is a less substantial aspect in the developed countries as they already have a good quality of infrastructure. Furthermore, Du et al. (2012) analyse highway density and highway length variables to understand the effect of infrastructure on the FDI. The study suggests that good quality of infrastructure for transportation boost the attractiveness of FDI.

Finally, institutional or organisational governance plays an essential role in determining the FDI flows amongst countries. Barassi \& Zhou (2012) apply the World Bank's Governance Indicator and find that corruption has a negative impact on FDI. The effect of corruption studied by taking FDI flows sample in 45 host countries proves that an increase in corruption would reduce FDI (Wei, 2000). However, the impact of corruption on FDI stocks become positive after adjusting the location choice. Intellectual property rights (IPR) also have a notable impact on FDI. IPR protection has a positive impact on FDI flows, which is higher when the FDI sources are more culturally distant (Du et al., 2013).

Furthermore, Holmes at al. (2013) propose the regulatory institution factor, which represents ways, including policy and laws that the government uses to control organisations. The finding suggests that the greater control of government has a negative impact on FDI. According to the evidence from most empirical studies, the quality of institutions in the host country is a significant factor for FDI inflows in developing countries (e.g., Wheeler and Mody 1992; Wei 2000; Globerman and Shapiro 2002; Benassy Quere et al. 2007; Daniele and Marani 2007). According to Globerman and Shapiro (2002), good governance delivers a positive impact on FDI inflows and outflows. The study also suggests that good governance boosts the abroad investment from domestic multicultural companies. Based on these theories, this study proposes the hypothesis as follows:

H1: as the amount of tax incentives increase, the FDI will also increase;

$\mathrm{H} 2$ : if government decrease the CIT rate, then the FDI will be higher. 


\section{Methods}

This paper uses a panel dataset of 22 countries that invest the most in Indonesia, which are Australia, Belgium, British Virgin Island, Canada, France, Germany, Hongkong, India, Italy, Japan, Republic of Korea, Malaysia, Mauritius, Netherlands, People's Republic of China, Philippines, Singapore, Switzerland, Taiwan, Thailand, United Kingdom, and the United States of America, throughout 19982018. The secondary data is obtained from various sources, which are Indonesia Investment Coordinating Board (BKPM), Indonesian Tax Law, International Monetary Fund (IMF) data, United Nation (UN) data, World Development Indicators (WDI), World
Governance Indicators, and CEPII (Research and Expertise on The World Economy). The data is processed using Stata/MP 14.2.

This study uses a gravity model to test the hypothesis that Tinbergen (1962) first introduced in international trade to analyse the impact of country-specific factors such as trading countries' income, distance, social, political, and institutional factors on trade. Disdier and Head (2008) found that trade cost has affected the trade flows negatively. They used geographical distance as a proxy of the transaction cost. Chaney (2018) argues that the gravity model's result is considered the most robust in empirical economies. The basic model of the gravity model in bilateral flow can be described by the specific equation as follows:

$$
\operatorname{Trade}_{a, b} \propto \frac{\left(G D P_{a}\right)^{\alpha}\left(G D P_{b}\right)^{\beta}}{\left(\text { Distance }_{a b}\right)^{\gamma}}
$$

Further, it can be described as follows:

$$
T F_{a b}=\beta_{0}\left(Y_{a}\right)^{\beta_{1}}\left(Y_{b}\right)^{\beta_{2}}\left(D_{a b}\right)^{\beta_{3}}\left(A_{a b}\right)^{\beta_{4}} u_{a b}
$$

where $T F_{a b}$ is the trade flow from a country a to country $\mathrm{b}, Y_{a}$ is the value of GDP of countries a, $Y_{b}$ is the value of GDP for countries b, Dab is the geographical distance between countries a and $\mathrm{b}, A_{a b}$ is other factors that can increase or decrease the trade flow between countries a and $\mathrm{b}$, and $u_{a b}$ is the distributed error term with $\mathrm{E}$ $\left(\ln u_{a b}\right)=0$.

The critical variables in this study are tax incentives and corporate income tax rates. As previous literature mentioned, they can affect the decision to invest in home countries since it can increase or reduce the transaction cost. Therefore, along with the distance variable, they can be used as proxies of transaction costs. This study uses the gravity model as a proper model to estimate the effect of tax incentives and corporate income tax rates on trade flow represented by FDI.

Scholars have used the gravity model to study FDI. Stone and Jeon (1999) used the model to examine the FDI flows within the Asia-Pacific region for 1987-1993. He found that market size and home country GDP have a significant impact on FDI flow. Another study by Benassy-Quere et al. (2007) used the model to observe the impact of institutional quality on FDI across OECD countries and some developing countries. It shows that most variables significantly impact FDI; however, the distance variable shows the unexpected result. De Mello-Sampayo (2009) and Kleinert and Toubal (2010) also study the determinants of FDI by deriving the gravity model from different theoretical models. The empirical model used to examine the relationship between tax incentives, corporate income tax rates, and FDI follows a model used by Leamer and Levinsohn (1994), which is a bilateral trade relationship that represents the function of income, population, and distance between two countries, as follows:

$$
\begin{aligned}
\text { RatioFDI }_{j t}= & \lambda_{0}+\lambda_{1} T_{i t}+\lambda_{2} \text { CIT }_{i t}+ \\
& \lambda_{3} \log G D P_{j t-1}+ \\
& \lambda_{4} \operatorname{Crisis}_{i t}+\lambda_{5} \log R E R_{i j t}+ \\
& \lambda_{6} I_{i t}+\lambda_{7} F_{i t}+\lambda_{8} \log D_{i j}+\xi_{i t}
\end{aligned}
$$

where:

- RatioFDI $I_{j t}$ is the ratio of inward FDI to Indonesia from country $j$ to Indonesian GDP at period $t$, in percentage, obtained from Indonesia Investment Coordinating Board (BKPM) and World Bank;

- $T I_{i t}$ is dummy variable of tax incentive in Indonesia $(0=$ before tax incentive is applied in 2007 and $1=$ otherwise) at 
period $t$, obtained from Indonesian Tax Law;

- $\quad C I T_{i t}$ is a dummy variable of the corporate income tax rate in Indonesia ( 0 if the rate is 25 per cent and 1 if otherwise) at period $t$, obtained from Indonesian Tax Law;

- $\log G D P_{j t-1}$ is a $\log$ of per capita GDP of partner countries $j$ at period $t-1$ in local currency unit, obtained from IMF and UN database;

- Crisis $i t$ is a dummy variable which represents the global economic shocks in 2007-2008 (1 if period 2007-2008 and 0 if otherwise);

- $\log R E R_{i j t}$ is a log of the relative exchange rate of Indonesian currency to country $j$ currency which is derived from the official exchange rate in Indonesia compared to country $j$, obtained from World Development Indicators;

- $I_{i t}$ is the index of institution quality, obtained from World Governance Indicators;

- $F_{i t}$ is the index of infrastructure quality, obtained from World Development Indicators;

- $\log D_{i j}$ is a $\log$ of the weighted distance between Indonesia and countries $j$, obtained from CEPII;

- $\quad \lambda_{i}$, where $i=0, \ldots \ldots, 8$ are parameters; $\xi_{i t}$ is the usual error term;

This study's data processing began with generating index value for two independent variables: institution and infrastructure. The institutional variable is measured by six indicators developed by Kaufmann, Kraay, and Zoido-Lobaton (1999), which are renewed by Kaufmann, Kraay, and Mastruzzi (2007), also called KKZ variables. Those six indicators are voice and accountability, political stability, government effectiveness, regulatory quality, law rule, and corruption control. Infrastructure variable is measured by individuals using the internet, mobile cellular subscriptions, air transport with passengers carried, freight, and registered carrier departures worldwide. The factor scoring used factor analysis which originated from Spearman (1904). Factor analysis is defined as a statistical technique for data reduction by describing a linear combination of all variables that consist of most information. In other words, it contains a group of correlated variables that is reduced to form a less value called factors. These factors then are used in regression with other explanatory variables.

Then, considering that the dimensions used in this study could lead to a potential spurious regression, it is essential to perform unit root tests before running the regression. This test enables to check whether the data is stationer. There are various options available for unit root tests; however, each option depends on different criteria to test all variables. This study uses Levin-Lin-Chu (2002) test since it could test almost all variables. The test was performed on per capita GDP partners and relative exchange rates variables. It showed that these variables are stationer in the log form.

To estimate the parameters, this paper uses a fixed-effects panel data technique by Sheperd (2016). This approach is appropriate since it can be used to control the country-pair heterogeneity. He emphasises that fixed-effect estimation is more straightforward in bilateral partnership measurement since it only requires the country-pairs' dummies that can be included in the model. Therefore, the fixed-effect gravity model can identify the effect of the variable that could be different bilaterally. In addition to the previous technique, this study also used the least square dummy variable (LSDV) suggested by Sheperd (2016) when estimating the variable omitted due to collinearity. Using this regression technique, the output will be able to estimate the coefficient of the distance variable. However, the estimated coefficients for the rest of the variables remain identical.

\section{Results and Discussion}

The observation consists of 440 balanced panel data of 22 countries for the period 1999-2018. The overall result can be shown in Table 4 to compare estimation using Fixed Effect and LSDV. The result shows that each parameter's coefficient using fixed effect and LSDV are equal except for distance.

The critical variable used to answer the research question is the dummy of a tax incentive. The estimated coefficient of tax incentives is negative and significant at one per cent, which means that the higher tax incentives, the lower FDI will flow. Interestingly, this result does not meet the expectation where tax incentives as a proxy of 
transaction cost should have a positive relationship with FDI. It indicates that foreign investors are more interested in other factors than tax incentives. As previously mentioned, tax incentive might also have disadvantages for home countries as it could cause higher tax payments when they have lower foreign tax credit policy. This result is in line with Fowowe (2013) study, which mentioned that tax incentives and FDI have a significant negative relationship in Nigeria.

Table 4. Model Panel of Fixed Effect and LSDV

\begin{tabular}{|c|c|c|}
\hline RatioFDI & Fixed Effect & LSDV \\
\hline \multirow[t]{2}{*}{ ti_i } & $-275.3301 * * *$ & $-275.3301 * * *$ \\
\hline & -0.0028 & -0.0028 \\
\hline \multirow[t]{2}{*}{ cit_i } & $-232.4939 * *$ & $-232.4939 * *$ \\
\hline & -0.0483 & -0.0483 \\
\hline \multirow[t]{2}{*}{ 1_lngdp_j } & $244.6164 *$ & $244.6164 *$ \\
\hline & -0.0619 & -0.0619 \\
\hline \multirow[t]{2}{*}{ crisis } & 108.9712 & 108.9712 \\
\hline & -0.2191 & -0.2191 \\
\hline \multirow[t]{2}{*}{ Inrer_ij } & $378.2821 * *$ & $378.2821 * *$ \\
\hline & -0.016 & -0.016 \\
\hline \multirow[t]{2}{*}{ inst_i } & $134.3315^{* *}$ & $134.3315 * *$ \\
\hline & -0.0142 & -0.0142 \\
\hline \multirow[t]{2}{*}{ inf_i } & $-166.5147 * *$ & $-166.5147 * *$ \\
\hline & -0.0217 & -0.0217 \\
\hline \multirow[t]{2}{*}{ lnd_ij } & 0 & 170.6116 \\
\hline & & 0.113 \\
\hline \multirow[t]{2}{*}{ _cons } & $-5190.0080 * * *$ & $-5190.0080 * * *$ \\
\hline & $(0.0064)$ & $(0.0064)$ \\
\hline $\mathrm{N}$ & 418 & 418 \\
\hline $\mathrm{F}$ & 3.5443 & 3.5443 \\
\hline r2 & 0.0600 & 0.0600 \\
\hline r2_a & -0.0077 & -0.0077 \\
\hline 11 & -3005.6154 & -3005.6154 \\
\hline bic & 6059.5146 & 6059.5146 \\
\hline aic & 6027.2308 & 6027.2308 \\
\hline
\end{tabular}

$* \mathrm{p}<0.10, * * \mathrm{p}<0.05, * * * \mathrm{p}<0.01$

However, the CIT rate coefficient is negative and significant at five per cent, which means the FDI inward is expected to increase as the CIT rate decreases. This result validates the hypothesis that CIT rate has a negative relationship with FDI. Theoretically, it is consistent with the Arbatli (2011), and Tang (2011) mentions the lower transaction cost means, the higher trade flows will occur. Furthermore, the findings also show that foreign investors rely more in CIT rate as a cost reduction compared to tax incentives. CIT rate is a statutory tax rate that is more certain than tax incentives. Since tax incentive required specific criteria and it becomes an administrative burden for investors. Moreover, it is less transparent as it could induce conflict of interest and political issues between large companies and lawmakers. It could also be the logic behind eliminating tax holidays in 1984 when the government prefers to reduce the CIT rate than grant tax incentives as stated previously. 
The next variable is the partner country's GDP per capita, which shows a positive relationship with FDI and significant at ten per cent. This sign confirms the theory that as countries' income increases, their ability to expand their economies will also follow (Mottaleb et al. 2010; Wheeler and Mody 1992; Chakrabarti 2001).

For crisis variable, it shows a positive sign but not significant. Then, relative exchange rate variable as a proxy of macroeconomic stability shows a positive and significant correlation which means that if Indonesian currency is stronger than the partner's currency, FDI will increase. It might happen since there are partners who put the macroeconomic stability as a priority to invest, and thus it becomes the reason to decide investment destination (Arbatli 2011; Noorbakhsh et al. 2001; Mottaleb and Kalirajan 2010). It is strengthened by the fact that after the Asian Financial Crisis in 1997-1998, Indonesia's GDP growth rose significantly and its FDI in 1999. Although Indonesian Rupiah experienced a high depreciation; initially, it slowly strengthened, which could be the sign for investors that Indonesia's economic stability has improved.

From non-economic factors, variables, institutional and infrastructure, only institutional-quality variables meet the expected sign. It has a positive relationship with FDI and significant at five per cent. It means that Indonesian institution still becomes an international issue and thus, the main reason for home countries to invest. North (1990) defines an institution as rules of the game, the constraints, guidance or structure that determine people's interaction and behaviour. The purpose is to minimise the uncertainty and reduce the transaction cost. It explains why investors prefer to invest in a country with a higher quality of an institution and sound management. Empirically, Benassy-Quere et al. (2007) also found a positive relationship with FDI in OECD countries and developing countries.

The sign of infrastructure variable does not meet the expectation because the five indicators of infrastructures might be highly correlated. As Wheeler and Mody (1992) stated, infrastructure quality only significantly impacts developing countries but not in developed countries as an investment destination. Therefore, the composed index value of infrastructure does not capture overall infrastructure availability. It means that the indicators chosen from many various infrastructure indicators are not adequate to represent Indonesia's infrastructure quality.

The last control variable, which is the distance, has a positive sign which means it is different from the expectation. The reason behind this finding could be the characteristic of distance in FDI is different from international trade. Since FDI is a long-term investment, home countries might not take distance into the primary consideration as a reduced cost for capital. Variable distance has a positive correlation to FDI was also found in Benassy-Quere et al. (2007), which also confirm that other host countries' criteria are more important than the distance in affecting investment decision.

\section{Conclusion}

The FDI is one of economic performance determinant of host countries. Therefore, many countries compete to create favourable conditions to make them as attractive investment destinations. One of them is by providing incentives, such as tax incentives. In this study, it can be shown that in the case of Indonesia, the taxation effect comes with a different result. Tax incentives have a negative relationship with FDI, which is not as expected with the hypothesis. However, the CIT rate effect is in line with the hypothesis that the lower CIT rate then, the greater FDI will flow. The result also shows that FDI would be greater if supported by another variable: high-quality institutions and macroeconomic stability.

Thus, the are several policy implications proposed from the previous result. First, the best approach to stimulate investment is to enhance institution quality. It can be done through reform on voice and accountability, political stability, government effectiveness, regulatory quality, law rule, and corruption control. Second, good macroeconomic stability works better than tax incentives. Therefore, the Indonesian government need to improve its macroeconomic environment. It is in line with Cleeve's (2008) findings that show political and macroeconomic environment are essential to 
attract FDI, supported by better investment regulation and infrastructures. Lastly, tax incentives negatively correlate with FDI, which means that the government needs to evaluate the tax incentive structure and mechanism or procedures of application, especially regarding the latest tax law draft (Omnibus Tax Law) that still offers tax holidays and tax allowance. It could lead to an effective and efficient tax policy implementation.

Some limitation of this study is as follows. Due to Indonesia's lack of tax data, this study cannot analyse the impact of tax incentives aggregately. This study does not consider the cost of implementing tax policy, and thus, the benefit and cost cannot be compared and analysed. James (2009) argues that an effective tax incentives policy is fulfilled when the accumulation of capital and revenue from investment and social benefits are more significant than government potential lost revenue and indirect cost from increased investment. Therefore, further comprehensive studies are required to measure the effectiveness of this policy.

\section{References}

Arbatli, E 2011, 'Economic Policies and FDI Inflows to Emerging Market Economies', International Monetary Fund Working Paper.

Asiedu, E 2002, 'On the determinants of foreign direct investment to developing countries: Is Africa different?', World Development, vol. 30, no. 1, pp. 107119.

Barassi, M, \& Zhou, Y 2012, 'The effect of corruption on FDI: A parametric and nonparametric analysis', European Journal of Political Economy, Vol. 28, pp. 302-312.

Bellak, C, Leibrecht, M, \& Riedl, A. 2008, Labour costs and FDI flows into Central and Eastern European Countries: A survey of the literature and empirical evidence', Structural Change and Economic Dynamics, 19(1), 17-37.

Benassy-Quere, A, Coupet, M, \& Mayer, T 2007, 'Institutional Determinants of
Foreign Direct Investment', The World Economy, 30, 764-782.

Chakrabarti, A. 2001, 'The Determinant of Foreign Direct Investment: Sensitivity Analyses of Cross-Country Regression', Kyklos, 54 (1), 89-114.

Chaney, T 2018, 'The Gravity Equation in International Trade: An Explanation', Journal of Political Economy, vol. 126, no. 1, pp. 150-177.

Cleeve, E 2008, 'How Effective Are Fiscal Incentives to Attract FDI to SubSaharan Africa?', The Journal of Developing Areas, vol. 42, no. 1, pp. 135-153.

Crespo, N, \& Fontoura, M 2007, 'Determinant Factors of FDI Spillovers - What Do We Really Know?', World Development, Vol. 35, pp. 410-425.

De Mello-Sampayo, F 2009, 'Competingdestinations gravity model: an application to the geographic distribution of FDI', Applied Economics, 41, (17) 2237-2253.

Devereux, MP \& Freeman, $H$ 1995, 'The impact of tax on foreign direct investment: empirical evidence and the implications for tax integration schemes', International Tax and Public Finance, 2, 85-106.

Disdier, AC \& Head K, 2008, 'The Puzzling Persistence of the Distance Effect on Bilateral Trade', Review of Economics and Statistics, 90(1): 37-48.

Du, J, Lu, Y, \& Tao, Z 2012, 'Institutions and FDI location choice: The role of cultural distances', Journal of Asian Economics, Vol. 23, pp. 210-223.

Dunning, H 2004, 'Institutional reform, FDI and European transition economies', in: R Grosse (ed), International business and governments in the 21st Century. Cambridge University Press.

Easson, AJ 1992, 'Tax Investment for foreign direct investment in developing countries', Australian Tax Forum, vol. 9, no. 4, pp. 387-440.

Fowowe, B 2013, 'Do fiscal incentives promote investment? Empirical evidence from 
Nigeria', The Journal of Developing Areas, vol. 47, no. 2, pp. 17-35.

Gujarati, DN 2004, 'Basic Econometrics', 4th Edition, McGraw-Hill Companies.

Government Regulation Number 18 the Year 2015 regarding income tax facility for capital investment in certain business sectors or regions (Republic of Indonesia).

Government Regulation Number 9 the Year 2016 regarding Amendment to Government Regulation Number 18 the Year 2015 regarding income tax facility for capital investment in certain business sectors or regions (Republic of Indonesia).

Government Regulation Number 78 the Year 2019 regarding income tax facility for capital investment in certain business sectors or regions. (Republic of Indonesia).

Hayakawa, K, Lee, HH, \& Park, D 2013, 'The role of home and host country Characteristics in FDI: firm-level evidence from Japan, Korea and Taiwan', Global Economic Review, Vol. 42, No. 2, pp. 99-112.

Hines, JR 1996, 'Altered states: taxes and the location of foreign direct investment in America', American Economic Review, 86, 1076-1094.

Holmes, R, Miller, T, Hitt, M, \& Paz Salmador, M 2013, 'The interrelationships among informal institutions, formal institutions, and inward foreign direct investment', Journal of Management, Vol. 39, pp. 531-566.

Hsu M, Junsang., L, Leon-Gonzalez R \& and Zhao Y. 2019, 'Tax incentives and foreign direct investment in China', Applied Economics Letters, 26:9,777780.

James, S 2009, 'Incentives and investments: evidence and policy implications, investment climate advisory services', World Bank Group, viewed 30 May 2020, <http://documents.worldbank.org /curated/en/945061468326374478/pdf/ 588160WP0Incen10BOX353820B01P UBLIC1.pdf >.
Jurcau, AS, Andreicovici, I \& Matis, D. 2011, 'The macroeconomic determinants of Romanian cross-border mergers and acquisitions', International Journal of Business Research.

Kaufmann, D, Kraay, A \& Mastruzzi, M 2009, 'Governance Matters VIII: Aggregate and Individual Governance Indicators, 1996-2008', Policy Research Working Paper Series 4978, The World Bank.

et al. 2010, 'The Worldwide Governance Indicators: Methodology and

Analytical', World Bank Policy Research Working Paper, No. 5430.

Keen M \& Mansour M 2009, 'Revenue mobilisation in sub-Saharan Africa: challenges from globalisation', IMF Working Paper: WP/09/157.

Klemm, A \& Van Parys, S 2012, 'Empirical evidence on the effects of tax incentives', International Tax and Public Finance, vol. 19, no. 3, pp. 393423.

Kleinert, J \& Toubal F 2010, 'Gravity for FDI', Review of International Economics. 18(1):1-13.

Law No. 78 the Year 1958 Concerning Foreign Investment (Republic of Indonesia).

Law No. 1 the Year 1967 Concerning Foreign Investment (Republic of Indonesia).

Law No. 11 the Year 1970 Concerning Amendment and Supplement to Law Number 1 of 1967 Concerning Foreign Investment (Republic of Indonesia).

Law No.7 the Year 1983 Concerning Income Tax (Republic of Indonesia).

Law No. 25 the Year 2007 Concerning Investment (Republic of Indonesia).

Levin, A, Lin CF, \& Chu, CSJ 2002. 'Unit root tests in panel data: Asymptotic and finite-sample properties', Journal of Econometrics 108: 1-24.

Maksimovska-Veljanovski, A, Pendovska, V \& Kjoseva, EN 2015, 'Open door tax policy for foreign direct investments in South-Eastern Europe: Tax Incentives and Flat Tax in Action', Inter Tax, vol. 43 , no. 11 , pp. $730-741$. 
Mateev, M 2008, 'Determinants of foreign direct investment in Central and Southeastern Europe: New Empirical Tests', 8th Global Conference on Business \& Economics, Florence, Italy.

Mengistu, B \& Adams, S 2007. 'Foreign direct investment, governance and economic development in developing countries', The Journal of Social, Political and Economic Studies, 32(2), 223.

Ministry of Finance Regulation Number 159/PMK. 010/2015 Concerning Granting of Corporate Income Tax Reduction Facility (Republic of Indonesia).

Ministry of Finance Regulation Number 103/PMK. 010/2016 Concerning Amendment to Regulation of the Minister of Finance Number 159/PMK.010/2015 regarding the Granting of Corporate Income Tax Reduction Facility.

Ministry of Finance Regulation Number 35/PMK. 010/2018 Concerning Granting of Corporate Income Tax Reduction Facility (Republic of Indonesia).

Ministry of Finance Regulation Number 150/PMK. 010/2018 Concerning Granting of Corporate Income Tax Reduction Facility (Republic of Indonesia).

Moosa, IA. 2002. Foreign Direct Investment: Theory, Evidence and Practice. Palgrave, London.

Mottaleb, K.A \& Kalirajan, K. 2010. 'Determinants of foreign direct investment in developing countries: a comparative analysis', Australian National University, Australia South Asia Research Centre.

Noorbakhsh, F, Alberto, P and Youssef, A. 2001, 'Human capital and FDI inflows to developing countries: New empirical evidence', World Development, 29, (9), 1593-1610.

Organisation for Economic Co-operation and Development 2008, Benchmark definition of foreign direct investment, $4^{\text {th }}$ edition, Organization for Economic
Co-operation and Development, viewed 20 April 2020, <https://www.oecd.org/daf/inv/invest mentstatisticsandanalysis/40193734.pd f>.

North, DC 1990, Institutions, Institutional Change and Economic Performance, Cambridge University Press, Cambridge.

Paun, D 2019, 'Tax competition and factors influencing the gross domestic product and foreign direct investments of CEE countries', Economic ResearchEkonomska Istraživanja, vol. 32, no. 1, pp. 876-893.

Popescu, GH 2014, 'FDI and economic growth in Central and Eastern Europe', Sustainability, 6(11), 8149-8163.

Riedl, A. 2010, 'Location factors of FDI and the growing services economy'. Economics of Transition, Vol. 18, No. 4, pp. 741761.

Sharma, K \& Bandara, Y 2010, 'Trends, patterns and determinants of Australian foreign direct investment', Journal of Economic Issues, Vol. 44, No. 3, pp. 661-676.

Sheperd, B. 2016, 'The gravity model of international trade (an updated version)', United Nation ESCAP.

Siegel, J, Licht, A, \& Schwartz, S 2013, 'Egalitarianism, cultural distance, and foreign direct investment: a new approach', Organization Science, Vol. 24, No. 4, pp. 1174-1194.

Stone, SF, \& Jeon BN. 1999, 'Gravity-model specification for foreign direct investment: a case of the Asia-Pacific economies', The Journal of Business and Economic Studies, 5(1), 33.

Tang, L 2012, 'The direction of cultural distance on FDI: attractiveness or incongruity?', Cross Cultural Management, pp. 233-256.

Thirwall, AP. 2011, Economics of development theory and evidence $9^{\text {th }}$ edition, Palgrave Macmillan, London.

Tocar, S 2018, 'Determinants of foreign direct investment: A review', Review of 
Economic and Business Studies, vol. 11, no. 1, pp. 165-196.

Wei, S 2000, 'How taxing is corruption on international investors?', Review of Economics and Statistics, 82(1), 1-11.

Wells, LT \& Allen, N 2001, 'Tax holidays to attract foreign direct investment: lessons from two experiments', in $\mathrm{L} \mathrm{T}$ Wells, N J Allen, J Morisset, \& N Prinia (eds), Using tax incentives to compete for foreign investment-are they worth the costs. Washington:
Foreign Investment Advisory Service. Occasional Paper 15. pp. 1-65.

Wheeler, D and Mody, A 1992, 'International investment location decisions: the case of US firms', Journal of International Economics, 33. 1-2, 5776.

Zee, HH, Stotsky, JG \& Ley, E 2002, 'Tax incentives for business investment: a primer for policy makers in developing countries', World Development, vol. 30, no. 9, pp. 1497-1516. 